\title{
Transformation of Cultural Identity of the Okokan Tradition in Kediri, Tabanan, Bali
}

\author{
Riza Wulandari, I Wayan Gede Lamopia \\ Department of Information Systems, Technology and Business Institute of STIKOM Bali, Denpasar, Indonesia \\ e-mail: rizawulandari@stikom-bali.ac.id
}

\begin{abstract}
Nowadays, the aesthetic value of Okokan performing art has shifted from the sign values replaced by exchange values. This shift is called as a phenomenon of transformation or change that occurs in the Okokan performing art. This study aims to examine the transformation that occurs in the Okokan Traditional Performing Art in Kediri, Tabanan, Bali. Qualitative method is used in solving the problems by taking data through observation, interview, verbal and visual documentation. Based on the findings, the process of the cultural identity transformation of the Okokan performing art includes the transformation of ritual values into profane values. In 1960, the Okokan tradition was carried out only when residents of Kediri had disease outbreak. Year after year, the function of Okokan performing art is shifted to commercialization. Beside of the function, there are changes in the music accompaniment. The existence of popular culture has led the Okokan Tradition being played with modifications of modern musical instruments and dances. The shift also occurs in the use of attributes and dance movements that have followed the current concept.
\end{abstract}

Keywords-Transformation, Cultural Identity, Okokan Performing Art, Bali.

\section{INTRODUCTION}

B ALI island has been known for its distinctive culture. The various traditions that reflect Balinese customs attract many people to take a closer look at the unique culture. Talking about Bali, it is difficult not to talk about Hinduism. The Hindu tradition can be said to be the "breath" of Balinese culture itself. This is because most of Balinese are Hindu. One of the famous Balinese philosophies is the concept of Tri Hita Karana. Lexically Tri Hita Karana means three causes of welfare, where Tri means three, Hita means prosperity, and Karana means cause. In essence, Tri Hita Karana means that the three causes of welfare are rooted in the harmonious relationship between humans and nature, humans and each other, and also humans and God. Balinese life is also often associated with art. More or less art has related with the harmony. Art and beauty are reflected in the social life of Balinese people. Art workers, such as dancers, painters, carvers, traditional drama performers, and so on are still part of the social system of Balinese society today.

Being a part of the cultural element, art performance is a form of performing art that is shown to the public by artists in order to provide entertainment that can be enjoyed by the audience. It is divided into 3 art classifications, namely fine arts, literary arts and performing arts. Performing arts are works of art that involve individual or group action at a certain place and time. Performances usually involve four elements, namely time, space, the artist's body and the relationship between the artist and the audience. From the point of view of West modern performing arts, performing art can be interpreted as an artistic activity involving performers who interpret a material to the audience through speech, music, movement, dance, and even acrobatics. The most important element of performing arts is the occurrence of direct interaction between the performer and the audience, although supporting elements such as films or recorded material are included [1].

Performing art is one of the pillars of the existence of cultural identity in Indonesia. The number of performing arts in Southeast Asia, 75\% are in Indonesia, while 25\% are in other Southeast Asian countries, such as Malaysia, Singapore, Brunei Darussalam, Myanmar, Thailand, Laos and Vietnam. The cultural potentials of this nation are very important to increase the dignity, respect and understanding of the meaning of humanity [2]. The percentage of quantitative data above shows that Indonesian nation is rich of arts and cultures. Indonesia has many styles and varieties of regional arts. The cultural or artistic background in Indonesia with a variety of regional cultures makes Indonesia be a heterogeneous nation of arts. This is one of Indonesian nation wealth in the field of art and culture and continues to develop based on the arts. [3]

Art becomes an aesthetic experience that is embodied in behavior or activities that can be enjoyed in real life. Indonesia is one of the countries that known for its arts from various parts of the region. The categories of art in Indonesia are very diverse, such as performing arts, art in the form of songs, art in the form of dance and others. One region that has contributed in introducing Indonesian arts is Bali island.

The potential of Bali island is inseparable from the framework of art, tradition and culture. Art in Bali is closely related to religious ceremonies, beliefs and customs. This series of cultural manifestations cannot be separated from one another. Hindu religious affiliation becomes a pillar for the arts that grow on the Bali island.

The development of arts on Bali island is currently one of the factors in increasing tourism that is able to generate foreign exchange for the Indonesia. The art and beauty of Bali is a reflection of the social life of the people there. The social system of Balinese society has so far been initiated by art actors such as dancers, painters, carvers, and others. [4]

The development of today's sophisticated and modern era has influenced the sustainability of performing arts, one of them is the Okokan Performing Art. As one of the tourist attractions in the field of arts, the Okokan Tradition always presents performances according to the meaning and norms of the ancestors time by time.

This is evidenced by a scientific study conducted by Riza Wulandari on the meaning of Okokan tradition by using a symbolic interactionalism perspective. Okokan traditional art is interpreted as a manifestation and representation of Ida Sang Hyang Widhi in interpreting noble values as the essence 
Table 1.

Data Collection Mapping

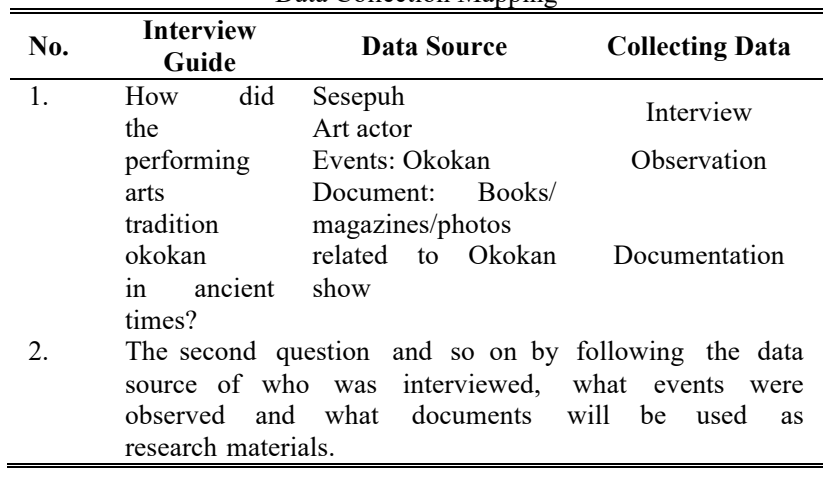

of harmony and life guidelines. Unfortunately, nowdays, the aesthetic value of cultural identity of Okokan performing art has shifted.This shift phenomenon can be seen from the exchange of values that resulted in the transformation of cultural identity. A research was conducted entitled the Okokan Tradition as Teaching Material in Balinese Language Learning at SMP and SMA / SMK. The results of this study indicate that in culture-based learning, culture is integrated as a tool for the learning process in motivating students when applying knowledge, working cooperatively and preparing linkages between various fields of science. Culture-based learning encourages students in imaginative, metaphoric, creative thinking and also culturally aware processes.

The development of this tradition year after year has increasingly changed, at this time the Okokan Tradition is no longer used as an epidemic of disease but has become an art performance staged by bringing colossal stories such as Giri Toh Langkir, Mahabarata, Nangluk Merana [5].

This tradition has undergoned a shift where previously it was a form of expelling disease outbreaks, but now it has shifted to performances that produce commodities. This is also reinforced by Wayan Windutama's research on a shift in meaning and aesthetic value, where initially this tradition was used as an repellent for disease outbreaks, but now has shifted to a commodity value called commodification. Wayan Windutama explained that there has been a commodification in the development of Okokan tradition as a tourist attraction which is divided into three parts namely Production, Distribution and Consumption Process. [6]

Based on the research above, related to the Transformation of Cultural Identity of the Okokan Performing Arts: Disruption or Innovation has never been carried out. The theme that was carried refers to the study of the existing literature which was also conducted for the first time. The research above only reviews inventory and documentation without analyzing the development of the Okokan performing arts in today's digital era.

A big question comes up, the transformation that occurred in the Okokan Tradition is a form of innovation carried out by art actors to maintain this art or becomes a tragedy that shifts the value of beauty values from the meaning of the Okokan tradition itself. Because of that, it is interesting to examine more deeply about the transformation processes of cultural identity that occur in Okokan performing art.

\section{METHOD}

In expressing the transformation of cultural identity that

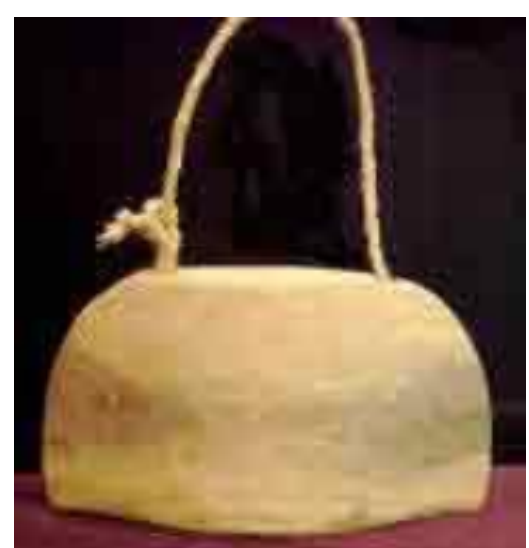

Figure 1. Okokan tool in the past .

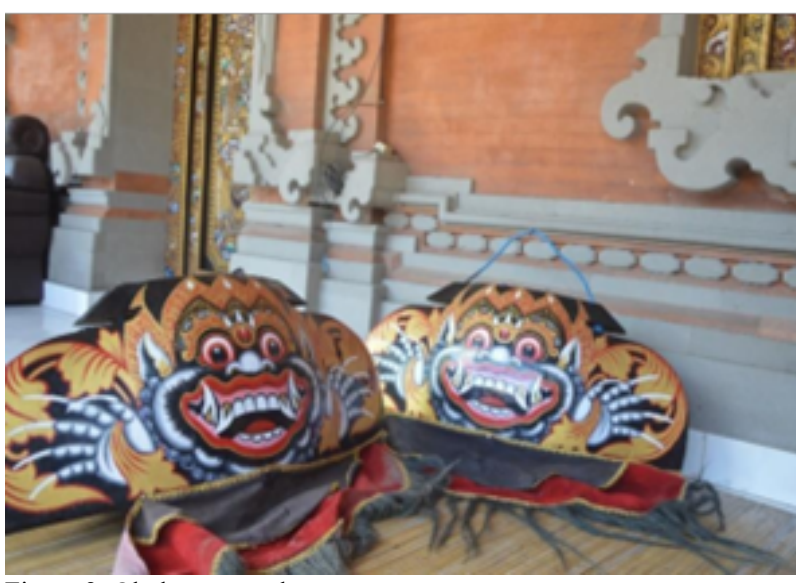

Figure 2. Okokan art tools.

occurs in the performing art of Okokan Tradition, it is necessary to use a systemic research approach.

Qualitative research is chosen to review social phenomena based on the social background and context to be observed. Qualitative research method aims to obtain a complete picture of something according to the human perspective. It relates to an idea, perception, opinion or belief of the informant and as a whole cannot be measured by numbers. [7]

The data sources selected in this study are divided into two, namely primary and secondary data. The primary data source here as the key informant is the Okokan artist in Brahma Siva Kencana studio which is classified based on gender and age. It is also important to understand the information from the elders who were chosen based on their organizational status and their existence in Okokan performing art.

The research subjects from secondary data were taken from scientific papers, magazines, books which are related to Okokan tradition. The problems in this study are lacks of references about the performing art. Therefore, stakeholders from the Culture and Tourism Office in Tabanan City were selected to help the researcher to find answers to this research study.

Beside from stakeholders, visual documents related to the okokan tradition are also used as a reference for secondary data. Mapping is a reference in collecting data using observation, interview and documentation techniques as seen in Table 1 .

The data that has been collected will be analyzed through several phases such as restating, reducing data, and drawing conclusions. [8] 


\section{RESULT AND DISCUSSION}

Geertz stated that culture is a pattern of understandings or meanings that are intertwined thoroughly in symbols that are historically transmitted, a system of conceptions inherited in symbolic forms in which humans communicate, preserve and develop their knowledge and attitude [9]. This opinion emphasizes that culture is a work of human who can develop their attitude towards life and are passed on from one generation to the next through a process of communication and learning, so that the inherited generation has a strong character in their life.

Culture becomes a bridge for the younger generation to maintain the national identity. Nowadays, various kinds of culture in Indonesia has pros and cons all along the time, one of them is the performing art. This part of Indonesian culture comes largely from traditional performance tradition that exist in various Indonesians ethnic. Performing art can be defined as a spectacle with artistic value such as drama, dance, music witnessed by audience. Almost every ethnic in Indonesia has arts or performing arts which reflect the characteristic of its people. In a community, art that is rooted in tradition has its own meaning for members of the community that is passed down from generation to generation and it is constant in the area. The relationship between art, society and the community influences each other. Besides that, it also gives an impact on changing thinking patterns and various developmental phenomena in the performing arts [10].

One of the problems that have been troubled by several parties involved in the life of the arts is the rapid cultural transformation that has an impact on the fading of the identity of the arts itself. The simplification of the understanding about socio-cultural transformation has been carried out by sociologists where the typology of society in modern or preindustrial types and modern or industrial types of society Cultural transformation are also considered a civilization of human society including a long and gradual process, not always linear and not always go straight. These stages of transformation produce a typology of society with the characteristic forms of life [11].

\section{A. History and Current States of Okokan Performing Arts}

The Okokan Tradition is one of the cultural elements that is currently run into a transformation. Located in the village of Kediri Tabanan, Bali Province, this performing art has caused unrest due to modernization. The touch of artistic gradations with a background of innovation makes the grip of this performing art lose its spiritual wraith. The inculcation of values contained in this tradition has begun to fade due to commercialization. Indonesian performing arts grew up in different ethnic environments. Traditions are inseparable from the performances or the realization of the performing art. Performing arts can be functionate as a summoner for supernatural powers, a complement in ceremonies and manifestations of the expression of beauty [12]. Beside that, performing arts are considered as fertility rituals, commemorating the life cycle from human birth to death, expelling disease outbreaks, protecting local communities from various threats, and also aesthetic presentations [13].

Traditional society in Indonesia perceives art as a hereditary manifestation that needs to be maintained. The view of traditional society is far from commercialization, they further strengthen the arts with inner expression and togetherness. Not only asa spectacle, but also the crucial thing that is presented in the performing arts is a traditional ritual that has been preserved from generation to generation. For traditional communities, especially the Priyayi, performing art is as a symbol of social status [14].

The rapid progress of the world has had an impact on several aspects of life, especially in the Okokan Traditional Performing Arts. Here are the Okokan Tools in the past as seen Figure 1 and 2.

Bali as a portrait representation of growing the values of cultural traditions which are currently still rooted and spreading. Starting from religious ceremonies, traditions in each region, customs, and arts which are carried out every day or at certain events. This is an attraction for domestic and foreign tourists. One tradition that still lacks of attention for both foreign and domestic tourists is the Okokan tradition. Okokan is generally made of wood which has a hole like a kentongan, but inside, it is filled with a stick called palit. These sound tools are generally mounted on domestic animals such as cows or buffaloes, which function as decorations or signs of the animal. Okokan is attached to domestic animals such as cows or buffalo as aesthetic of the animal's mark.

In the past, a group of agrarian societies were always close to the tradition of farming. Okokan was also used as a means of entertainment or a magical ritual. Okokan was a mystical activity to ward off the plague. At dusk, the residents go around the village to ward off evil spirits that spread disease outbreaks. They brought a kind of bamboo stick and were beaten repeatedly which resulted sounds. In Kediri Tabanan, it is not bamboo kentongan that is carried, but the usual okokan hanging on the neck. In ancient times, disease outbreaks were considered by the surrounding community as the initiation of spirits, therefore they had to be expelled by sounding sound-producing tools. So that the local people of Kediri village use okokan which is played by several people.

The okokan tradition has now begun to be developed in various sub-districts in Tabanan or villages in Tabanan. According to information from existing community leaders from Kediri village, the okokan tradition or tektekan merana in Kediri is a hereditary tradition which at first the community did not know when it started. It means that this tradition has existed since immemorial time. This is because there are no written inscriptions that have written about the history of the Okokan. The actors of the Okokan culture are the entire Kediri village community consisting of children, adolescents to adults, both boys and girls.

The process of cultural activities begins with prayer activities at each banjar hall. Furthermore, people who "negen" or bear the okokan, will choose the okokan to be paraded later. After selecting them, they marched out of the banjar hall and performed a mapekeling ceremony with the okokan, then after that the okokan was played for the first time in front of their respective banjar halls, continued to the other banjars, meaning that after the attraction is carried out in the banjar itself, the okokan parade it walks towards other banjars while playing okokan. 


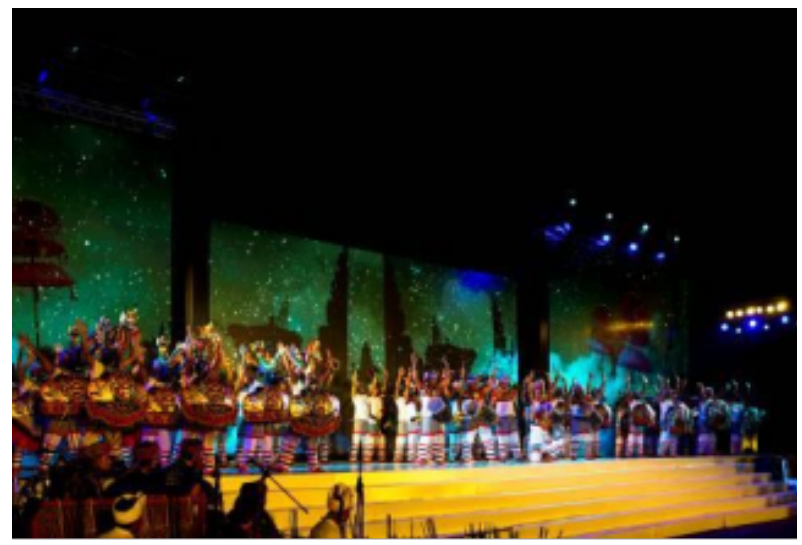

Figure 3. Okokan performing arts at the Soundrenaline event.

The breath of rituals from the social and cultural system of society in ancient times shifted to the aspects of meaning and time, which was carried out on the Pengerupukan Night before Nyepi Day. The aesthetics of the beauty of the ritual began to be dragged away as if it lost its meaning and only became a show to be shown. The performing arts of the Okokan Tradition which is carried out on the night of Pengerupukan still maintains the social status, which is led by the elders of Kediri Tabanan Village. After experiencing a "second" transformation, by the millennial year, , the Okokan Tradition was dragged down by the flow of digitalization. by the times, the mindset and economic pressure, Okokan Tradition has turned into a "contemporary" performing art. It means that beside bringing the traditional background of Kediri Village from generation to generation, it is also shown as an objective beyond the interests of tradition, one of them is a musical event. One of the studios that poisoned the okokan tradition was the Brahmana Diva Kencana Studio. It is undeniable that the transformation of sacred values to change towards profane values was done deliberately by the actors of the Okokan Tradition.

The transformations follow modern developments, starting from music accompaniment, clothing attributes, and performance arenas. Modification of dance movements is also a shift by following the "contemporary" style as seen in Figure 3 and 4 . The arrival of socio-cultural changes caused by the journey of industrial society and the market economy as well as the orientation of the arts will gradually shift, in other words, it will be increasingly oriented towards urban culture. So that it will become a performance that is packaged only in artistic nature without the beauty of a hereditary identity. The movements in the Okokan Tradition are now not just stomping the feet simultaneously, but there are also modified dances to enrich the performing arts, so that they are involved more expensive.

\section{B. Transformation of Okokan's Cultural Identity: Disruption or Innovation}

According to Stella [15], cultural identity is the feeling (emotional significance) of a person to share (sense of belonging) or be affiliated with a certain culture. The society, which is divided into groups, then carries out cultural identification, where each person considers themselves as a representation of a particular culture [15]. There are some characteristics of cultural identity, namely (1) cultural

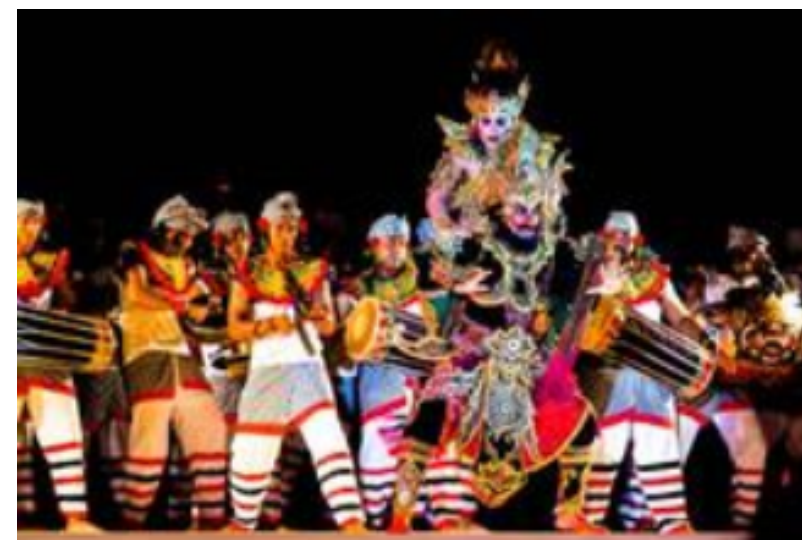

Figure 4. Okokan performing art nowadays.

identity is the center of our personality appearance. We will become more aware of our own cultural identity when we live in other people's culture and interacting with several people from different cultures (2) Our cultural identities can sometimes survive in an ever- changing social context; (3) cultural identity is multi- faceted. The more cultural differences we face, the more cultural identities of other people face us. As a result, the more we are able to compare our cultural identities with people's culture [16].

The elements contained in today's culture are starting to face anxiety. Some of the elements in it have experienced a shift in meaning, value, and even sign. The shift that occurs is a transformation process that will continue to develop by the time. Istanti and Kun Zachrun also added that the shift in nuance or culture is essentially a form of transformation that follows the current development and thoughts of the copyist. The transformation process is a change that occurs slowly. It is unpredictable when it will start and how long it will end, depend on the factors that influence it. it is comprehensive and continuous and the changes that occur are closely related to the emotional (value system) which exist in society. Transformation contains a time dimension and the occupying socio-cultural changes that arise through a long process that is always related to the activities that occur at that time. Thus transformation is a change that occurs from a previous state to a completely new state. These changes are due to a change of societal conditions. The changes occurs from internal factor such as people's mindset and external factors such as the environment. Thus, people who have experienced a different mindset will also have different ways in looking at things [17].

Exploring transformation cannot be separated from the phenomenon of innovation or disruption. The question of transformation itself has an innovative impact or a phenomenon of meaning deconstruction. The concept of broad innovation is not limited to products. Innovation can be in the form of ideas, methods or objects that are perceived by someone as something new. Innovation is also often used to refer to changes that are perceived as something new by the experiencing society. However, in the context of marketing and in the context of consumer behavior, innovation is associated with a new product or service. [18] 'New' to refer to a product that has really never existed in the market and 'new' in the sense that there are different things which are 
improvements from previous products that consumers have encountered in the market. Economic and social success thanks to the introduction of new ways or new combinations of old ways of transforming inputs into outputs that create major changes in the relationship between use value and prices offered to consumers and / or users, communities, societies and the environment [19].

The disruption referred to in this study is the deconstruction of meaning. Fukuyama defines disruption according to the lexical meaning of the word. Disruption means disturbance or chaos. According to him, a society that is conditioned by the power of information tends to respect the values that are upheld in democracy, namely freedom and equality. Freedom of choice is high as a right, while all types of hierarchy (in religion, politics, government, business, etc.) are undermined by their regulatory power and coercive tendencies. Fukuyama recognizes the advantages or benefits arising from technological changes, so that society becomes an "information society" (information society).

Welfare, democracy, awareness of human rights and concern for the environment, are examples. According to Fukuyama, the consequences of new technological developments are not necessarily positive. The informationsociety, in any country, is characterized by deteriorating social conditions. Crime and social chaos create life inconvenience, even in relatively prosperous urban centers. Kinship and family as social institutions were shaken, while the number of divorces increased and the birth of unwanted children increased. Fukuyama does not reduce social problems to a moral crisis or the hypocrisy of the times. He pointed to statistical data on crime rates, divorce, the birth of children without fathers, the declining quality of education, and the loss of trust in social life. This phenomenon is an indicator of the emergence of two serious disturbances, namely the weakening of social ties and the fading of the common values that become social capital. The relationship between the two factors, social ties and common values, is of cultural, economic, socio-political and technological characteristics. The cumulative complexity becomes a great disruption (great disruption) to social life [20].

The transformation that occurs in the okokan performing art cannot be separated from the influence of the current environment which demands a change. [21] revealed that tektekan art was codified in the village of Kediri Tabanan which was motivated by the existence of a market ideology. The process of commodification of textures takes place through stages, starting with a performance request from a certain party. The existence of a bargaining or negotiation stage between the two parties gives an agreement regarding the costs borne by the art service tenant. The impact that occurs is in the form of changes in the meaning of okokan in various contexts, both changing the meaning of the assessment and in the context of time and power relations [21]. Economic and social success are caused by the introduction of new events or new combinations of old ways of transforming inputs into outputs that create major changes in the relationship between use value and prices offered to consumers and / or users, communities, societies and the environment [19]. The Okokan Tradition, which should have been sacred, has shifted according to market demand. The

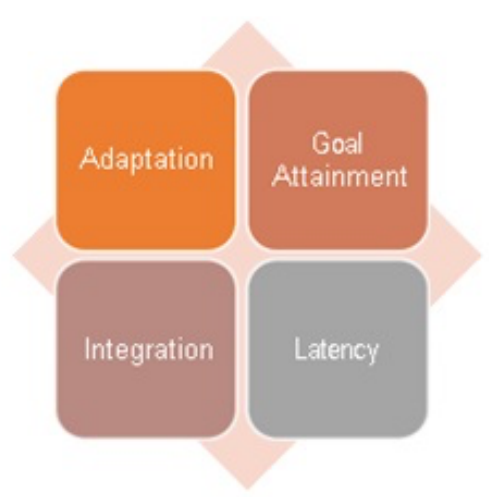

Figure 5. Talcott Parson's AGIL (Adaptation, Goal, Integration, Latency) Theory.

concept of innovation is the reason for the transformation to leave the sacred grip of a tradition. Talcott Parson revealed that there are 4 things that are used in analyzing the phenomenon that causes the shift in the performing arts of the Okokan Tradition, as seen in Figure 5.

Society or a group is a social system consisting of parts or elements that are interrelated and are mutually united in balance. Changes that occur in one part will also bring changes to other parts. Society is seen as a system in which all social structures are integrated into one, each has a different function but interrelated and creates consensus and social order and all elements will adapt to each other both to internal and external changes in society. In order to be able to survive, the community or group must carry out the four components as shown above. The transformation of the performing art of the Okokan tradition that is played by actors begins with an adaptation. Art actors must pay attention to situational needs that come from outside. They must adapt to the environment then adapt it to their needs, one of them is the users of performing arts services such as hotels, tourism places, and other consumers during the ceremony.

The adaptation process boils down to the Goal Attainment desired by the performers of the Okokan Tradition. This goal is supported by the local community who hope that the transformation will increase the commodity value of the Okokan performing art. The third component is Integration, in which the community art actors and stakeholders integrate each other to find agreement and awareness that there needs to be a change in the Okokan performing art as a form of action in the midst of modernization. The last process, namely Latency (Pattern Maintenance), motivation and action must be maintained and renewed so that the performing art of the Okokan Tradition will not be eroded by the times.

The emergence of modernism started the emergence of various forms of modernism's products, one of them is the development of technology, mass media and entertainment, as well as thoughts that led to rationality with realistic scientific foundations. Modernization included the process of exclusion of classical works, because modernity essentially took a position against old things for the creation of new things. So the emergence of something new, wether it a culture or an item that makes modernization continue to develop from what it was before. [23]. The development of the modern world, which is currently increase more complex, has been proven to have influenced Indonesian culture, one 
of them occurs in the Okokan Traditional Performing Arts. The shift in meaning and cultural identity which is motivated by the way of dealing with modernization by creating innovation in the end causes the loss of the true sacred meaning. Referring to the AGIL concept, this shift is not a deterioration but a form of the existence of the actors so that this performance art continues to be of interest to all audiences.

\section{CONCLUSION}

Okokan performing art is inevitably dragged into the modernization that causing a transformation of cultural identity where in the ancient times, the art of Okokan served as an exorcism of disease outbreaks. But nowadays, it is an art that is shown for the public. The sacredness of Okokan traditions begins to fade as if it just a group of people play a dance without any soul in it. It is inseparable from the development of industrialization which leads to commercialization. The process of cultural identity transformation that occurs in Okokan performing art is not only in its function, but also in musical accompaniment, time, and attributes. The shift that occurs is unseparated from environmental factors, so they can be exist in the midst of modernization. It is appropriate to Talcott Parson's theory that there are four components namely, adaptation, goal attainment, integration, and latency. So, the society can survive in the midst of modernization.

\section{REFERENCES}

[1] J. Volz, How to Run a Theatre: A Witty, Practical, and Fun Guide to Arts Management. Back Stage Books, 2004.

[2] I. M. Bandem, Wayang Wong, Denpasar: Bali Mangsi Press, 2001

[3] T. K. Yeningsih, "Nilai-nilai budaya dalam kesenian tutur pm toh (cultural values in art of pm toh)," Harmonia: Journal of Arts Research and Education, vol. 8 no. 2, pp. 214-223, 2007 doi: 10.15294/harmonia.v8i2.794

[4] I. N. P. Janiasa, Okokan, Denpasar, 2017

[5] R. Wulandari, I. G. A. W. Upadani, and S. Alfarisi, "Okokan tradition: understanding noble value in the frame of symbolic interactionalism,"
International Journal of Applied Sciences in Tourism and Events, vol. 4 no. 1, 2020 doi: 10.31940/ijaste.v4i1.1607

[6] W. Windutama, I. N. Sunarta, and N. M. S. Wijaya, "Komodifikasi dalam pengembangan tradisi okokan sebagai atraksi wisata di desa kediri, tabanan," Jurnal Master Pariwisata (JUMPA), vol. 6 no. 2, pp. 452 - 469, 2020 doi: 10.24843/JUMPA.2020.v06.i02.p10

[7] L. J. Moleong, Metodologi Penelitian Kualitatif. Bandung: PT. Remaja Rosdakarya, 2007

[8] H. K. Mohajan, "Qualitative research methodology in social sciences and related subjects," Journal of Economic Development, Environment and People, vol. 7 no. 1 , pp. 22-48, 2018

[9] N. T. Alexei, "Theoretical methodological bases of the sociocultural transformation," International Journal of Environmental and Science Education, vol. 11 no. 18, pp. 11993-12003, 2016

[10] N. H. H. Garbum, Tradition, Tourism and Textile: Creativity at the Cutting Edge, Burlington: Ashgate, 2000

[11] R. Mohamed, Saving Capitalism and Democracy. USA: Palgrave Macmillan, 2013

[12] S. Sedyawati, Pertumbuhan Seni Pertunjukan. Jakarta: Sinar Harapan, 1981

[13] R. Soedarsono, Seni Pertunjukan Indonesia Dari Persepektif Politik, Sosial, dan Ekonomi. Yogyakarta: Gadjah Mada University Press, 2003

[14] K. M. Alan, Social and Cultural Transformation. Kheper: Home: Creative Commons License, 2009

[15] T. T. Stella, Communication Across Culture. New York: The Guilford Publication, Inc., 1999

[16] A. Liliweri, Makna Budaya Dalam Komunikasi antar Budaya, Jakarta: Binakarya, 2011

[17] B. L. Handayani, "Transformasi perilaku keagamaan (analisis terhadap upaya purifikasi aqidah melalui ruqyah syar'iyah pada komunitas muslim jember," Jurnal Sosiologi Islam, vol. 1 no. 2, pp. 71-86, 2011

url: http://jurnalfisip.uinsby.ac.id/index.php/JSI/article/view/1/

[18] T. Suryani, Perilaku Konsumen; Implikasi Pada Strategi Pemasaran, Yogyakarta: Graha Ilmu, 2008

[19] C. B. Hawkins, Consumer Behavior: Building Marketing Strategy. USA, Boston: Mc. Graw-Hill, 2005

[20] F. Fukuyama, The Great Disruption: Human Nature and the Reconstitution of Social Order, London: Profile Books, 1999

[21] A. N. A. S. Tenaya, Mendekonstruksi wacana komodifikasi kesenian tektekan di desa kediri, kecamatan kediri, kabupaten tabanan, bali. Denpasar: Universitas Udayana, 2018

[22] J. Tittenburn, "Talcott parsons' economic sociology," International Letters of Social and Humanistic Sciences, vol. 13, pp.20-40, 2014

[23] A. Giddens, The Consequences of Medernity. Cambridge: Polity Press, 1990 